\title{
The Role of Religious Belief in James's Pragmatism
}

\author{
James Flaherty
}

Marquette University

Ralph Barton Perry notes that pragmatism is the movement that begins with William James's misunderstanding of Charles Sanders Peirce.' Perry's observation is perceptive in two respects. First, James clearly misunderstood Peirce's pragmatic principle. Indeed, James's interpretation of Peirce's pragmatic point of view caused Peirce to change its name from pragmatism to "pragmaticism"- a term Peirce thought "ugly enough to be kept safe from kidnappers." Peirce's strong reaction to James's misunderstanding is not without warrant. For, while Peirce stressed the universal and long-term consequences of a pragmatic way of thinking, James emphasized its particular and immediate ones. Secondly, although James himself acknowledged Peirce as the founder of pragmatism, the pragmatic movement did not truly begin with Peirce. Rather, pragmatism became a movement only when it became the object of James's concern. Perhaps, more than any other factor, James's inimitable manner of presentation-whether in the lecture hall or in print-brought the pragmatic way of thinking into the popular consciousness. By his own admission, James discovered in Peirce's principle a means of making philosophy a matter of public debate and concern. As Cornel West observes, James's contribution "consists of popularizing the personal and moral implications of the pragmatic perspective initiated by Peirce."3

Indeed, a concern for the personal and the moral implications of pragmatism dominates James's thinking. From early to late in his philosophical career, he occupies himself, in West's words, with "the heroic energies and reconciliatory strategies available to individuals." No less consistent than James's concern for the personal and moral implications of pragmatism is his concern for its religious ones. The Gifford Lectures of 1901-02 (later published 
as The Varieties of Religious Experience), as well as many of James's popular essays (e.g. "The Will to Believe") serve as examples of this concern. But perhaps the most striking example of James's religious concern occurs in his more programmatic essays - those essays wherein James articulates his own pragmatic point of view. For example, in his Berkeley lecture of 1898, "Philosophical Conceptions and Practical Results," James not only introduces Peirce's pragmatic principle, but he does so by employing it to resolve a debate between materialism and theism. Ultimately, as he goes on to argue, pragmatism decides in favor of the latter. Moreover, in his Lowell Institute Lectures of 1906 (later published as Pragmatism), religious themes occur throughout the work. After reading the lectures, James's friend and frequent correspondent, Oliver Wendell Holmes, Jr., remarked, "I now see, as I have seen in his other books that I have read, that the aim and end of the whole business is religious." Holmes's remark is striking, especially when we recall that James did not formally associate himself with any religious tradition, and he once described himself as having "no living sense of commerce with God."

The purpose of this paper is to attempt to explain why pragmatic and religious themes are so closely intertwined in James's thought, even though he never considered himself to be a religious person. By way of procedure, I will begin by presenting James's understanding of God. As we shall see, James argues that the meaning of the concept of God is found in the difference it makes in the life of the believer. What is the difference that the concept of God makes in a believer's life? James provides the most dramatic answer to this question in his semi-autobiographical essay of 1895, "Is Life Worth Living?" Literally speaking, he claims, the difference that God makes in the life of the believer can be a matter of life and death. For, if the believer should become caught in the grip of melancholy and/or depression-even to the point of contemplating suicide - the disposition to believe, James argues, can free him from that grip, and to consider living anew. In a similar manner, James also maintains, from an epistemological perspective, that the disposition to believe can free us from the grip of old ways of thinking, and to begin thinking anew. The 
ability to move beyond our old patterns of thinking, and thereby to develop new ideas and new truths, is a central theme in James's pragmatism. For this reason, I want to argue, he always harbored a deep sympathy and respect for religious belief, even though he never considered himself to be a religious person.

\section{I}

As I noted above, James both introduces and misinterprets Peirce's pragmatic principle in his Berkeley address of 1898 , "Philosophical Conceptions and Practical Results." Nonetheless, James's misunderstanding of Peirce's pragmatism is revealing. It is revealing both of James's own empiricist leanings (a bias he acknowledges toward the lecture's conclusion) and his understanding of what constitutes the meaning and truth of a concept. James reformulates Peirce's principle in the following words: "And I should prefer for our purposes this evening to express Peirce's principle by saying that the effective meaning of any philosophic proposition can always be brought down to some particular consequence, in our future practical experience, whether active or passive; the point lying rather in the fact that the experience must be particular, than in the fact that it must be active. To take in the importance of this principle, one must get accustomed to applying it to concrete cases."”

James misinterprets Peirce's principle in two respects. First, while Peirce argues that the meaning of a concept consists in its universal and long-term consequences-i.e., in consequences that lead to the formation of habits-James maintains the opposite. According to him, the meaning of a concept resides in consequences which are particular and immediate. James's empiricist leanings determine, in no small way, his reformulation of Peirce's pragmatic principle; they also highlight a second point of difference between the two thinkers. For, while Peirce applies his principle to the pragmatic conception of meaning, James extends its application to that of truth. As James goes on to say, "Suppose there are two different philosophical definitions... If, by supposing the truth of the one, you can foresee no conceivable practical consequence to 
anybody at any time or place, which is different from what you would foresee if you supposed the truth of the other, why then the difference between the two propositions is no difference-it is only a specious and verbal difference, unworthy of further contention." Where Peirce carefully distinguishes between questions of meaning and truth, James conflates the two. This conflation of truth and meaning results in James's belief that the difference which a concept makes in a particular situation is the criterion for its meaning and truth. John Dewey is perceptive in commenting upon the establishment of this criterion in James's thinking. Dewey writes:

The principal reason which led James to give new color to pragmatic method was that he was preoccupied with applying the method to determine the meaning of philosophical problems and questions, and that moreover, he chose to submit to examination philosophical notions of a theological or religious nature. He wished to establish a criterion which would enable one to determine whether a given philosophical question has an authentic and vital meaning or whether, on the contrary, it is trivial and purely verbal; and in the former case, what interests are at stake when one accepts and affirms one or the other of the two theses in dispute. ${ }^{9}$

In James's mind, the most significant criterion - from a pragmatic point of view - is the difference that a concept makes in our lives; therein lies the criterion for its meaning and truth. James writes: "There can be no difference which doesn't make a difference - no difference in abstract truth which does not express itself in a difference of concrete fact, and of conduct consequent upon the fact, imposed on somebody, somehow, somewhere, and somewhen." James's reformulation of Peirce's pragmatic principle, when applied to notions of a theological or religious nature, has significant and interesting implications. 
On James's view, religion is predominantly "a living practical affair."" More specifically, religion, according to him, must concern itself with making sense out of the triumphs and tragedies of human living. Indeed, he is quite critical of dogmatic and scholastic theology for losing sight of this fact. For example, James argues, in his 1898 lecture, that many of the scholastic descriptions and formulations about God do not satisfy "practical Americans." They do not make a concrete difference in the life of the believer. "How does God's 'aseity' come home to you?", James asks his audience. "What specific thing can I do to adapt my self to his "simplicity'?"12 But, while he criticizes many of the abstract formulations of the scholastics, James does not discount all such formulations. In fact, he argues that the notions of God's omniscience and justice are quite legitimate because, in James's words, they have "practical connections with life." In other words, the notions of God's omniscience and justice make a concrete difference in the life of the believer. James respectively refers to these concepts by saying: "With the one [God] sees us in the dark, with the other he rewards and punishes what he sees."13

In James's opinion, then, the criterion for the meaning and truth of religious concepts lies in the consequences of their practical application. Ultimately, religious concepts must concern themselves with the concrete, practical affairs of men and women. Until we apply the concepts, say, of God's omniscience or justice to the particular situations of our human living, they remain, on James's view, empty abstractions. Once applied, however, the question about their meaning and truth becomes relevant and vital. Moreover, if we adjust our behavior because of these concepts, their meaning and truth become even more significant, insofar as they make a concrete difference in our lives. According to James, therefore, the meaning of the concept of God lies in the difference it makes in the conduct of the believer. For this reason, he argues, the only adequate conception of God is a pragmatic one, that is, the conception of a God who makes a difference in the life of the believer. As James puts it, "Now the principle of practicalism says that the very meaning of the conception of God lies in those differences which must be made in our experience if the conception 
be true." 14 In the Berkeley lecture of 1898, James employs this pragmatic conception of God to settle the debate between theism and materialism.

In the lecture, James argues that the vitality of the debate between theism and materialism depends upon certain conditions. First, he claims that the debate is only vital to a consciousness that is "prospective" in nature. And second, the debate is vital only in a universe that is largely "open." If consciousness is primarily "retrospective," and the universe is already a settled affair, then, James claims, the debate is merely an exercise in mental gymnastics, and it is not a very fruitful exercise at that! For, to James's way of thinking, it makes no sense to debate about whether God or matter is ultimately responsible for a universe in which the facts are already "bagged and captured." In such a universe, the choice between theistic and materialistic positions literally makes no difference; the facts are just as they are, and belief in God or matter does nothing to change them. James writes: "Calling matter the cause of [the universe] retracts no single one of the items that have made it up, nor does calling God the cause augment them."1s Thus, James maintains that where the universe is a closed and settled affair, and consciousness is largely retrospective, the debate between theism and materialism is idle and inconsequential. He continues: "Thus if no future detail of experience or conduct is to be deducted from our hypothesis, the debate between materialism and theism becomes quite idle and insignificant. Matter and God in that event mean exactly the same thing - the power, namely, neither more or less, that can make just this mixed, imperfect, yet completed world - and the wise man is he who in such a case would turn his back on such a supererogatory discussion."16

James believes, however, that consciousness is not primarily retrospective, nor is the universe a closed and settled affair. Rather, he claims that consciousness is essentially prospective in nature, and the universe is very much an open one. Under these conditions, the debate between theism and materialism becomes vital, and the pragmatic principle helps to resolve the issue between them. Under the conditions of a prospective consciousness and open universe, it makes a great difference whether God or matter is ultimately 
responsible for the universe. To James's way of thinking, the difference is between a universe which ends in triumph and one which ends in tragedy. The materialist's conception of the universe, according to James, ends in tragedy. More specifically, the materialist conceives of a universe consisting of gradually depleting resources and diminishing energies; it is a universe steadily advancing toward its final end. James writes: "For, according to the theory of mechanical evolution, the laws of redistribution of matter and motion, though they are certainly to thank for all the good hours which our organisms have ever yielded us and for all the ideals which our minds now frame, are yet fatally certain to undo their work again, and redissolve everything that they have once evolved." "17 By contrast, the theist draws a radically different picture of the universe-i.e., one that is lively, and whose final word is triumph. Indeed, James argues, the concept of God guarantees such a triumph. Thus, he notes that what theism may lack in conceptual clarity it gains in practicality. James writes:

The notion of God, on the other hand, however inferior it may be in clearness to those mathematical notions so current in mechanical philosophy, has at least this practical superiority over them, that it guarantees an ideal order that shall be permanently preserved. A world without God in it may burn up and freeze, but we then think of Him as still mindful of the old ideals and sure to bring them to fruition; so that, where he is, tragedy is only provisional and partial, and shipwreck and dissolution not the absolute final things. ${ }^{18}$

In this text, James is not being disingenuous or naive in making this claim. He knows from personal experience the struggles and trials that comprise human existence. ${ }^{19}$ But, as the text reveals, he argues that these struggles and trials do not have the final word; they are, at best, "provisional and partial," and the theistic conception of the universe guarantees their provisional nature. In 
such a universe, the struggles and trials that initially weigh us down are eventually overcome. Thus, James criticizes materialism not for what it is, but for what it is not. That is to say, materialism cannot support the hopes and ideals that lay deep in the human heart. And these hopes are, in James's words, "the truly philosophic concern." Thus, with respect to the materialistic conception of the universe, he writes: "We make complaint of it ... for what it is not-not a permanent warrant for our more ideal interests, not a fulfiller of our remotest hopes."20 To James's way of thinking, then, only the theistic conception of the universe can guarantee such hopes.

The hopes which theism guarantees, moreover, are not fanciful or remote. They do not await fulfillment in some distant, unknown future. If they did so, James says, they might "mean nothing to the sane mind." They would remain, appropriately, beyond the bounds of our attention and concern. James's conception of God, however, is that of a God who makes a difference throughout our life's journey-past, present and future. He writes: "If there be a God, it is not likely that he is confined to making differences in the world's latter end; he probably makes differences all along its course. Now the principle of practicalism says that the very meaning of the conception of God lies in those differences which must be made in our experience if the conception be true." ${ }^{\text {"21 }}$ The empirical bent of James's pragmatism comes to the fore in this remark. The meaning of the concept 'God' is found in the particular and concrete differences which the concept makes in the conduct of the believer. The superiority of theism's claim shows itself, then, not only in a redeemable future, but in the immediacy and particularity of the present moment. The pervasiveness of theism's cogency is both near and far. And it is a cogency that philosophy (i.e. pragmatism) can rationally depict. James says that "the whole function of philosophy ought to be to find out what definite difference it will make to you and me, at definite instants of our life, if this world-formula or that world-formula be the one which is true."22 According to James, the world-formula suggested by theism makes such a difference, and for that reason it is meaningful and true. And, as we shall see in the following section of this 
paper, the difference which the theistic world-formula makes is not only a matter of an open and closed universe, but also one of life and death.

\section{II}

I mentioned earlier James's personal knowledge of the struggles and trials that comprise human existence. James is known to have wrestled with depression throughout his life, and at a particularly difficult time, he even contemplated suicide. ${ }^{23}$ Thus, one cannot help but read James's essay of 1895, "Is Life Worth Living?", as a testament to his own struggle and eventual triumph over this disease. With clearly autobiographical overtones, the essay directly addresses the question of suicide, and attempts to offer a rationale for rejecting it. James frames the purpose of the essay in the form of a question: "What reasons can we plead that might render such a brother (or sister) willing to take up the burden again?"24 In framing this question, James is not naive about his purpose in the essay, insofar as he is acutely aware that his plea cannot be heard by the person for whom "reflection is impotent to arrest [depression's] headway." ${ }^{2 s}$ The essay, therefore, is not intended for those suffering so deeply that they cannot employ their rational powers in a significant way.

Curiously, James casts the problem of suicide in religious terms. The melancholic disposition that leads to suicide, James says, is an "essentially religious disease."26 On his view, then, the disease is due to the contradiction that life presents to the religious consciousness. The contradiction is one between the belief in the essential concord of the world as a whole (the view that the official religions espouse) and its apparent discordant facts. From an empirical perspective, the world is a complex assortment of discordancies — of triumph and tragedy, good and evil, love and cruelty. Furthermore, there seems to be no overarching plan or purpose to the wild array of these hard facts. Such facts, James writes, "exist in indissoluble partnership; and there gradually steals over us, instead of the old warm notion of a man-loving Deity, that of an awful power that neither hates nor loves, but rolls all things 
together meaninglessly to a common doom."27 Caught in this contradiction, the religious consciousness becomes susceptible to depression and, perhaps, to the contemplation of suicide. In James's words, the contradiction becomes for the consciousness of the believer a "melancholy-breeding puzzle." 28

James argues that the resolution of this puzzle depends upon the activation of two human resources. The first is the heroic disposition, which he believes is constitutive of human nature; the second lies in the activation of the human disposition to religious belief. James appeals first to the heroic or combative disposition. This disposition, he believes, runs "deeper" than the melancholic disposition, and is able to counteract it. James presents two options for the melancholic personality in confronting the "melancholybreeding puzzle" that life presents. On the one hand, she may reject the "monistic superstition" of a concordant world, allow the discordant facts of life to take hold, and without guilt or shame choose suicide. On the other hand, however, the melancholic person may reject the same superstition, and choose to combat the real discordancies that surround her. James, of course, argues for the latter option. He writes: "The sovereign source of melancholy is repletion. Need and struggle are what excite and inspire us; our hour of triumph is what brings the void."29

In James's mind, then, we only escape the grip of the "melancholic-breeding puzzle" when we actively struggle to make the discordant facts of human living more concordant. The option for suicide, therefore, is really a pseudo-escape; it only confirms the superstition of a concordant world and the puzzle's hold upon us. The heroic disposition, to the contrary, does not deny the discordance of the present world, but neither does it accept discordance as the final word; rather, it chooses to struggle to make the world more concordant. That is to say, the heroic disposition struggles to make the world different. James records historical examples of peoples (such as the Waldenses) who displayed great heroism in the midst of horrendous circumstances. Inspired by such examples, he offers the following counsel: "Life is worth living, no matter what it brings, if only such combats may be carried to successful terminations and one's heel set on the 
tyrant's throat. To the suicide, then, in his supposed world of multifarious and immoral nature, you can appeal-and appeal in the name of the very evils that make his heart sick there-to wait and see his part of the battle out." 30 Thus, by exercising the heroic disposition, the melancholic personality is able to find an initial resolution the puzzle that life presents.

According to James, however, the appeal to the heroic disposition is only a first step; it serves merely as a "half-way stage" to an escape from melancholy's hold. Ultimately, an appeal to a second disposition is required-i.e., the disposition to religious belief. Religious belief, James writes, is the "faith in the existence of an unseen order of some kind in which riddles of the natural order may be found explained." ${ }^{31}$ Religious belief, then, places its trust in the existence of a concordant order that will eventually harmonize the discordancies of the present one. For this reason, James believes that the appeal to the heroic disposition represents only a "half-way stage" towards bringing peace to the melancholic personality. In short, the heroic disposition lacks a sense of the purpose or telos of the struggle to overcome the discordancies of the present world. In James's mind, fighting for the sake of fighting is not sufficient. We must ask ourselves, what are we are fighting for? Religious belief, he maintains, provides the answer by affirming that we are fighting for a concordant order. Ultimately, the promise of such an order makes the struggle in particular and living in general worthwhile. Thus, with the activation of the disposition to believe, melancholy's hold is broken-not by suicide-but by the belief in an eternal, concordant order, which, James believes, is worth struggling to establish.

It is important to note that James does not attempt to prove the existence of this eternal order; rather, he simply argues for the right to believe in it. James writes, "I wish to make you feel ... that we have a right to believe the physical order to be only a partial order; that we have a right to supplement it by an unseen spiritual order which we assume on trust, if only thereby life may seem to us better worth living again." ${ }^{22}$ Playing the devil's advocate, James raises a few possible objections to his claim. The first comes from a certain scientific mentality, which might argue against the 
existence of any order or world other than the present one. According to this mind-set, all the fundamental facts of the universe are already available, and science simply fills in the picture. But, James argues, such a claim actually does violence to the very notion of the scientific imagination, and he urges us to consult the history of science as a proof. When we examine this history, James contends, we see that some of the most significant scientific discoveries resulted from "absolutely new" conceptions. Thus, taking into account the revolutionary novelty of many scientific discoveries, James maintains that the fundamental facts concerning the nature of the universe are not already available; they are not, as he likes to say, "bagged and captured." Rather, on his view, our understanding about the final order of the universe is still unfolding. Thus, he declares, "No! our science is a drop, our ignorance a sea. Whatever else be certain, this at least is certain,- that the world of our present natural knowledge is enveloped in a larger world of some sort of whose residential properties we at present can frame no positive idea." ${ }^{\text {33 }}$

The second objection that James's raises to his claim that we have a right to believe in an ultimately concordant world comes from "agnostic positivism." According to this objection, however different a future universe might be from the present one, we do not have the sufficient evidence to posit it. Curiously, this objection agrees with James's contention that all the facts of the universe are not yet established. The agnostic positivist objects, however, to the right to draw any specific conclusion about the universe's ultimate nature. Agnostic positivism contends that we have no right to believe one way or the other-whether the ultimate order is temporal and discordant or eternal and concordant. Basically, agnostic positivism raises an objection on the grounds of insufficient evidence. James's response to the objection is insightful and humane: no decision of significant import-whether in science, ethics, religion, or life in general-is made with absolutely conclusive evidence. He claims that our most important decisions are always comprised of a number of "maybes." The genuine scientist, no less than the person of faith, typically acts without absolute certainty, and sometimes risks his reputation and 
life in the process. For this reason, James says, "Not a victory is gained, not a deed of faithfulness or courage done, except upon a maybe; not a service, not a sally of generosity, not a scientific exploration or experiment or textbook, that may be a mistake. It is only by risking our persons from one hour to another that we live at all. And often enough our faith beforehand in an uncertified result is the only thing that makes the result come true."34

James's response to the objections raised by science and agnostic positivism makes clear his own position. First, we live in a universe that is largely "open." Contrary to the first objection, James claims that not all the fundamental facts about the universe are "bagged and captured," and that significant facts about the nature of the universe still await discovery. Against the objection raised by agnostic positivism, he argues that sometimes belief is the only thing that makes such discovery possible. To put the point somewhat simply, we will never know if our conjectures about the nature of the universe are true unless we put them into practice. In reading James on this point, however, we must be careful. He is not saying that believing something makes it true. Rather, James argues that oftentimes belief is the only way we can even begin to know if something might be true. As Dewey remarks, "Moreover it may be that, in order to discover the proofs which will ultimately be the intellectual justification of certain beliefsthe belief in freedom, for example, or the belief in God-it is necessary to begin to act in accordance with this belief." ${ }^{35}$ The most significant questions in life, James maintains, will never be sufficiently addressed if we wait for absolutely conclusive evidence. On his view, such evidence is rarely (if ever) forthcoming.

The question about the ultimate nature of the universe, and our purpose within it, poses such a question. Barring the possibility of absolutely conclusive evidence about the nature of the universe, our fundamental disposition towards this question makes all the difference in the world. On the one hand, for the melancholic and suicidal personality, the universe remains a puzzle that only breeds despair; the facts are just what they are, and there is nothing we can do to change them. For the heroic and believing disposition, 
on the other hand, the puzzle stands to be resolved (due to the heroic disposition), and in an ultimate way (due to the disposition to believe). Thus, according to James, the type of disposition we bring to the question, "Is life worth living?", is a crucial one, and the difference that the disposition to believe makes is crucial. Ultimately speaking, it is a difference between life and death. "Refuse to believe," writes James, "and you shall indeed be right, for you shall irretrievably perish. But believe, and again you shall be right, for you shall save yourself. You make one or the other of two possible universes true by your trust or mistrust,- -both universes having been only maybes, in just this particular, before you contributed your act."

\section{III}

In a letter of 1904, written to James Henry Leuba, James reveals his own personal position regarding religious belief and God. James writes:

My personal position is simple. I have no living sense of commerce with God. I envy those who have, for I know the addition of such a sense would help me immensely. The Divine, for my active life, is limited to abstract concepts which, as ideals, interest and determine me, but do so faintly, in comparison with what a feeling God might effect, if I had one. It is largely a question of intensity, but differences of intensity may make one's whole center of energy shift. ${ }^{37}$

Such a revelation may strike the reader of James as strange, especially in light of his consistent defense of the right to believe. Is James simply selling himself short? Or, does his lack of "feeling" for the Divine express the truth of the matter? And if, indeed, he did lack such a feeling, how can we account for the pervasiveness of the "religious concern" in his pragmatism? 
In terms of the first two questions, I would offer the following response. First, James is not selling himself short. Although raised in the Christian tradition, he ultimately distanced himself from any allegiance to a specific religion. Indeed, later in the same letter to Leuba, James speaks about growing out of his "entanglement" with Christianity. Secondly, in his classic work, The Varieties of Religious Experience, James argues that the origin of religious belief lies in one's "feeling" for God. "I do believe," he writes, "that feeling is the deeper source of religion..." ${ }^{38}$ One of the main tasks of Varieties is to document the great diversity of such feelings in the lives of particular religious individuals. By contrast, theological and/or philosophical conceptions about these feelings, James maintains, "are secondary products, like translations of a text into another tongue." ${ }^{39}$ According to James, then, the essence and origin of religious belief lies in an individual's personal feeling for God. If one has no such feeling or personal experience of the Divine, then it is difficult to muster any type of authentic belief. James, by his own admission, lacks the necessary experiential component that could ground such belief. Thus, in response to the first two questions raised above, James is not selling himself short. By his own admission, he simply lacks the "feeling" necessary for "a living sense of commerce with God." We are left, therefore, with the question why he remains such a consistent advocate for the importance of religious belief.

James himself indicates a possible response to this question in his letter to Leuba. In the letter, he equates religious belief with the possibility of an "energy shift" in the life of the believer. If the religious feeling is present in a person, James suggests, it can create a difference that is decisive in his or her life. Indeed, we have seen instances of such a difference throughout our discussion. We have seen, for example, that the concept 'God' means the possibility of a world evolving towards triumph rather than tragedy. In a world of discordant facts, 'God' is the guarantor of an eternally concordant order. His 'omniscience' sees us in the darkness, and his 'justice' awards us for our goodness. But perhaps, the most dramatic difference the concept 'God' makes in the life of the believer-especially for the believer caught in the grip of 
melancholy and despair-is to see that his life is well worth living. In short, James maintains that religious belief provides the melancholic or depressed personality the possibility of living anew. As John McDermott puts it, "Belief for James is a wedge into the tissue of experience, for the purpose of liberating dimensions otherwise closed to the agnostic standpoint."40

The agnostic standpoint does not apply to religious experience alone. It also applies to our cognitive experience, especially when traditional ways of thinking prevent us from considering new and different ways. On James's view, pragmatism provides philosophy with such a way. More specifically, he claims, pragmatism offers a way of mediating between the endless disputes that tend to paralyze the philosophical tradition. As he declares in his Pragmatism lectures of 1907, "The pragmatic method is primarily a method of settling metaphysical disputes that otherwise might be interminable. Is the world one or many?-fated or free?material or spiritual? - here are notions either of which may or may not hold good of the world; and disputes over such notions are unending." 41 As we have seen, James claims that we settle these disputes by considering the practical differences that each of these notions makes in our lives. This is not to say, however, that pragmatism settles philosophical disputes once and for all. Much to the contrary, James argues that the ideas that settle philosophical disputes function well until they meet some new experience that calls these ideas into question. This experience, in turn, can generate a new idea, and this idea is "adopted as the true one." Truth, as James says,

is always a go-between, a smoother-over of transitions. It marries old opinion to new fact so as ever to show a minimum of jolt, a maximum of continuity. We hold a theory true just in the proportion to its success in solving this problem of 'maxima and minima.' But success in solving this problem is eminently a matter of approximation. We say that this theory solves it on the whole more satisfactorily than that theory; 
but that means more satisfactorily to ourselves, and individuals will emphasize their points of satisfaction differently. To a certain degree, therefore, everything is plastic. ${ }^{42}$

James's point is not that everything is "plastic" insofar as everything is relative. Rather, he argues that everything is "plastic" in that nothing is known with absolute certainty. On James's view, our knowledge about ourselves and the world we inhabit is fallible; it is, as he puts it in the previous citation, "eminently a matter of approximation."

Always an astute commentator of James, John Dewey offers two important reflections for our consideration. First, he reminds us that "James was an empiricist before he was a pragmatist, and repeatedly stated that pragmatism is merely empiricism pushed to its legitimate conclusions." observes that James's empiricism differs from its more classical expression in one crucial aspect. The empirical verification of a concept's meaning and truth, according to James, is prospective rather than retrospective; he looks to consequent rather than antecedent phenomena for the ultimate verification of a concept. In other words, James is not primarily concerned with the repetition of old facts, but with the creation of new ones. Of course, the creation of new facts demands a spirit of belief, since, prior to our efforts of testing, we cannot secure the verification we seek. For this reason, a religious standpoint is superior to an agnostic one, insofar as it provides the disposition necessary for achieving such verification. Indeed, Dewey is helpful in reminding us about the crucial difference between James's empiricism and that of his predecessors. James's stress on the verification of consequent phenomena relies, in no small way, upon a spirit of belief for its success. For this reason, he remained, throughout his philosophical career, a consistent advocate for the importance of religious belief, even though he did not consider himself to be a particularly religious person. 


\section{Endnotes}

1. See Ralph Barton Perry. The Thought and Character of William James, abridged version (Cambridge: Harvard University Press, 1948), 281.

2. Charles Sanders Peirce. "What Pragmatism Is," reprinted in Charles Sanders Peirce: Selected Writings, ed. with intro. Philip P. Weiner. (New York: Dover Publications, 1958), 186.

3. Cornel West, The American Evasion of Pragmatism: A Genealogy of Pragmatism (Madison: University of Wisconsin Press, 1989), 55.

4. Ibid., 54.

5. Oliver Wendell Holmes, Jr. Holmes-Pollock Letters, ed. Mark De Wolfe Howe, vol. 1 (Cambridge: Harvard University Press, 1941), 140.

6. James makes this remark in a letter to James Leuba. See The Letters of William James, ed. Henry James, vol. 2 (New York: Krause Reprint Co.), 211.

7. William James, "Philosophical Conceptions and Practical Results," reprinted in The Writings of William James, ed. with intro. and preface John J. McDermott (Chicago: University of Chicago Press, 1977), 349.

8. Ibid.

9. John Dewey, "The Development of American Pragmatism, " reprinted in The Philosophy of John Dewey, ed. with intro. and commentary John J. McDermott (Chicago: University of Chicago Press, 1973), 45-46.

10. James, "Philosophical Conceptions and Practical Results," 349.

11. Ibid., 356.

12. Ibid., 356.

13. Ibid.

14. Ibid., 355.

15. Ibid., 351.

16. Ibid.

17. Ibid., 353.

18. Ibid., 354.

19. As we shall shortly see, James is known to have struggled with depression throughout his life.

20. James, "Philosophical Conceptions and Practical Results," 354.

21. Ibid.

22. Ibid., 349. 
23. See The Writings of William James, ed. with intro. and new preface by John J. McDermott (Chicago: University of Chicago Press, 1977), xx.

24. William James, "Is Life Worth Living," reprinted in The Will to Believe and Other Essays in Popular Philosophy (New York: Dover Publications, 1956), 38.

25. Ibid.

26. Ibid., 39.

27. Ibid., 41-42.

28. Ibid., 42.

29. Ibid., 47.

30. Ibid., 49.

31. Ibid., 51.

32. Ibid., 52.

33. Ibid., 54.

34. Ibid., 59.

35. Dewey, "The Development of Pragmatism," 48.

36. James, "Is Life Worth Living?," 59.

37. James, The Letters of William James, 211.

38. William James, The Varieties of Religious Experience, reprinted with foreward by Jacques Barzun (New York: Penguin Books, 1958), 358.

39. Ibid.

40. Ibid., $x \times x$.

41. William James, Pragmatism and the Meaning of Truth, intro. A.J. Ayer (Cambridge: Harvard University Press, 1975), 28.

42. Ibid., 35.

43. Dewey, "The Development of Pragmatism," 48.

\section{Works Cited}

Dewey, John. The Philosophy of John Dewey. Edited with introduction and commentary by John J. McDermott. Chicago: University of Chicago Press, 1973.

Holmes, Oliver Wendell, Jr. Holmes-Pollock Letters. Vol. 1. Edited by Mark De Wolfe Howe. Cambridge: Harvard University Press, 1941. James, William. The Will to Believe and Other Essays in Popular Philosophy. New York: Dover Publications, 1956.

. The Varieties of Religious Experience. Reprinted with foreward by Jacques Barzun. New York: Penguin Books, 1958. 
The Letters of William James. Vol. 2. Edited by Henry James. New York: Krause Reprint Co., 1969.

. Pragmatism and The Meaning of Truth. Introduction by A.J. Ayer. Cambridge: Harvard University Press, 1975.

. The Writings of William James. Edited with introduction and preface by John J. McDermott. Chicago: University of Chicago Press, 1977.

Peirce, Charles Sanders. Charles Sanders Peirce: Selected Writings. Edited with introduction and notes by Philip P. Weiner. New York: Dover Publications, 1958.

Perry, Ralph Barton. The Thought and Character of William James. Abridged version. Cambridge: Harvard University Press, 1948.

West, Cornel. The American Evasion of Philosophy: A Genealogy of Pragmatism. Madison: University of Wisconsin Press, 1989. 